\title{
各種石灰石粒子から熱分解生成された $\mathrm{CaO}$ 粒子の $\mathrm{SO}_{2}$ に対する反応性の比較
}

\author{
湯 沢恩*・架 谷昌 信 \\ 名古屋大学工学部 化学工学科 ${ }^{\dagger}$
}

\begin{abstract}
FBC の排ガス脱硫用石灭石の原石種選定に対する基礎資料を得る目的で，種々の石灰石から熱分 解生成される $\mathrm{CaO}$ 粒子の $\mathrm{SO}_{2}$ に対する反応性を, 反応温度, $700 \sim 1100^{\circ} \mathrm{C}$, 試料粒径, $5 \sim 1000 \mu \mathrm{m}$ の実験条件下で，TGAを用い比較検討した。その結果，

$d_{p}=5 \mu \mathrm{m}$ の極徽粒子を用いた場合, 反応は大略化学反応律速下で進行し, 同時に, 用いた石灰石 種間には, $\mathrm{SO}_{2}$ に対する基礎的反応性の相異はほとんぞ認められなかった.

$d_{p} \geq 300 \mu \mathrm{m}$ の粒子を用いた場合には， $\mathrm{CaO}$ 粒子内空陌容積は熱分解温度の上昇と共に減少する が，とくに，さんご礁石灰石 (CRR) から熱分解生成される粒子内空隌容積は, 用いた他の石灰石に 比し，著しく高い值を示した。

総括反応速度に与兄る空隙払散抵抗の影響は, 粒径増大に伴い顕著となるが, 試料 $\mathrm{CaO}$ 粒子内空 隙容積に強く依存する.すなわち, 原石種および熱分解温度によりこの影響は異なる。この結果, CRR から熱分解生成された $\mathrm{CaO}$ 粒子の $\mathrm{SO}_{2}$ 吸収容量が最大を示した。
\end{abstract}

\section{緒}

現在, 石炭流動層然焼 (FBC) の排ガス脱硫法として, 高温反応吸収法が広く適用されているが，通常使用され る $0.3 \sim 5 \mathrm{~mm}$ 程度の粒状石灰石の利用効率が極めて低 いことが大きな問題となっている．この点に関し，既に 多くの検討 ${ }^{1,2,3,5)}$ が行われ, その主たる原因の 1 つは, 反 応生成固体である $\mathrm{CaSO}_{4}$ の分子比容が反応固体 $\mathrm{CaO}$ の約 3 倍の值を有するため, 反応進行に伴い粒子表面近 傍の空陣が閉塞され $\mathrm{SO}_{2}$ の粒子内部への拡散を阻害し, 見掛け上反応が停止することにより，多量の $\mathrm{CaO}$ が未 反応のまま放出されることにあると考光られている。

ところで, 我が国に打いて, 石灰石は多種, 多量に産 出されることが知られているが，石灰石原石によって， それから熱分解生成される $\mathrm{CaO}$ 粒子の空隚性状, 反応 性などが異なるため，石灰石種間に脱硫剤としての優劣 を生ずることが考えられる．このことから，石灰石原石 種の選定は, FBC 排ガスの脱硫にとって, 重要視すべ き点の 1 つ考えられる. しかしこの点に関する検討 は，米国活いては比較的活発行行わているが，我が 国の研究状況はかならずしも十分ではないと思われる。

本研究は, 上記観点から, 石灰石種選定の基礎資料を 得る目的で, とくに, 他の石灭石に比し多孔性に富んだ さんご礁石灰石 (Coral Reef Rock, CRR：徳之島産), セメント用原材料として多用されている田原, 藤原産石 灰石，FBC 排ガスの脱硫剤として一部試用されている 中山産石灰石および高純度, 高結晶性である岡山産寒水

\footnotetext{
$+\mp 464$ 名古屋市千種区不老町

* 群馬大学工学部建設工学科

干376 桐生市天神町 1-5-1
}

石の 5 種を試料選び, これらからの熱分解生成 $\mathrm{CaO}$ ๑ $\mathrm{SO}_{2}$ に対する基礎的反応性， $\mathrm{CaO}$ 粒子内空隙性状と 反応に伴う空隙変化などについて検討し，脱硫剤として の有用性を比較し考察を行った。すなわち，本研究目的 に沿って, 前報)で得られた結論に基づき, $d_{p}=5 \mu \mathrm{m} の$ 極徽粒子を用い，極力空隙拡散抵抗の影響を取り除いた 実験条件下で，まず，基礎的反応性を比較し検討した。 ついで, $d_{p}=300 \sim 1000 \mu \mathrm{m}$ の比較的大粒径粒子を用 い, 通常の $\mathrm{FBC}$ 石炭燃焼温度に相当する $800 \sim 1000^{\circ} \mathrm{C}$ に打汀る熱分解生成物の空隙性状, 硫酸化反応に伴亏空 隙および粒子形態の変化などを実験的に追跡し, 粒径増 大に伴ら反応性低下を比較し, 石灰石種間の脱硫剤とし ての優劣を考察した，一部について，前報)で述べたグ レインモデル ${ }^{b)}$ に基づく固気反応解析の結果と比較し, 考察の参考とした.

\section{1. 実}

\section{験}

Table 1 に, 使用した 5 種の石灰石の真密度, 空吵率 およびこれらの熱分解生成物の真密度, $\mathrm{CaO}$ 含有率を 示した. CRR の空吵率が他に比し, 著しく高いこと, 寒水石からの熱分解生成物は純 $\mathrm{CaO}$ に近いことなどが 注目すべき点である. Table 1 に示した石灰石を, 呼び 径 $5 \mu \mathrm{m}$ マイクロシーブ，60 12 メッシュタイラー節 にて，先述した各種粒径に篩い分けし，実験供試料に市 てた。

反応装置は, 前報4) と同様, 白金ヒーターによる外壁 加熱式反応炉，白金試料ホルダー，その直下の PtRh 13\%-Pt 熱電対，温度制後装置などを含むミクロ熱天科 (理学電気製, 高温型) および流量調節用ニードルバルブ 
Table 1 Physical properties of raw limestones and their calcines

\begin{tabular}{|c|c|c|c|c|}
\hline \multirow{2}{*}{ Sample } & \multicolumn{2}{|c|}{ Limestone } & \multicolumn{2}{|c|}{ Calcines } \\
\hline & $\begin{array}{c}\text { True } \\
\text { Density } \\
\left(\mathrm{g} / \mathrm{cm}^{3}\right)\end{array}$ & $\begin{array}{c}\text { Porosity } \\
\text { (-) }\end{array}$ & $\begin{array}{c}\text { True } \\
\text { Density } \\
\left(\mathrm{g} / \mathrm{cm}^{3}\right)\end{array}$ & $\begin{array}{c}\mathrm{CaO} \\
\text { Content } \\
\text { (wt \%) }\end{array}$ \\
\hline Kansuiseki & 2.75 & 0.07 & 3.58 & 99 \\
\hline Nakayama & 2.78 & 0.07 & 3.01 & 83 \\
\hline CRR & 2.71 & 0.28 & 3.21 & 92 \\
\hline Tahara & 2.77 & 0.09 & 3.38 & 96 \\
\hline Fujiwara & 2.73 & 0.07 & 3.33 & 86 \\
\hline
\end{tabular}

付きロータメータ，ガス切換えコックなどを内蔵したガ ス混合器 (小島製作所製, GM-3A） から構成されてい る.

反応実験にあたり，まず， $\mathrm{N}_{2}, \mathrm{O}_{2}, \mathrm{~N}_{2}-\mathrm{SO}_{2}$ の 3 種の ガスを反応师内溥入し，各々を所定流量に設定する。

$\mathrm{N}_{2}-\mathrm{SO}_{2}$ ガスの流入を停止し，上記測定点の温度を既定 の熱分解温度まで昇温する. 試料を $10 \sim 15 \mathrm{mg}$ ミクロ 天科 (長製, Jupiter $\mathrm{M}_{1}-20$ ) とて精秤後試料ホルダー に設置し，試料重量の減少が認められなくなるまでこの 温度での加熱を継続し熱分解の 終了を確認する。この 後, 測定点温度を所定の硫酸化反応温度まで $10^{\circ} \mathrm{C} / \mathrm{min}$ にて昇または降温し，定常状態を確認した後， $\mathrm{N}_{2}-\mathrm{SO}_{2}$ 混合ガスを $\mathrm{N}_{2}$ ガスの一部と瞬間切換えして硫酸化反応 を開始させ, 試料重量の経時変化を連続測定した。

また，各反応段階に拉汁る粒子の空吵性状および外形 を水銀ポロシメーター（カルロエルバ社製）および走查 型電子顕微鏡 (SEM, 日本電子製, TSM-25S) に上り測 定し, 硫酸化反応化伴う空隌変化あるいは粒子形状変化 を観察した，なお，反応条件は下記の通りとした。 反応 温度; $T=700-1100^{\circ} \mathrm{C}$, 反応気体濃度; $\mathrm{SO}_{2}=0.0035-$ $0.0040 \mathrm{~m}^{3} / \mathrm{m}^{3}, \mathrm{O}_{2}=0.02-0.03 \mathrm{~m}^{3} / \mathrm{m}^{3}, \mathrm{~N}_{2}$ ニバランス, 試料粒径； $d_{p}=5-1000 \mu \mathrm{m}$.

\section{2. 理 論解析}

著者らはさきに, 寒水石からの熱分解生成 $\mathrm{CaO}$ と $\mathrm{SO}_{2}$ との反応について，グレインモデルに基づいて，そ の総括反応速度を解析し, 用いた解析手法により, 粒径 増大に伴う空隙閉塞に関する実験結果を大略再現し得る ことを報告した ${ }^{4)}$. 従って, 本研究においても, $\mathrm{CaO}$ 粒 子の反応進行過程を粒子内空㭞払散抵抗の影響を受ける 場合と乞の影響を受けない場合とに大別し球形グレイン モデルを基調として以下のごとく理論解析を行う.

本反応例, $\mathrm{CaO}+\mathrm{SO}_{2}+1 / 2 \mathrm{O}_{2}=\mathrm{CaSO}_{4}$, は $\mathrm{SO}_{2}$ 濃度 に関し 1 次, $\mathrm{O}_{2}$ 濃度関し 0 次であることが知られて おり，従ってグレインモデルに基づけば，空隙および固 相拡散抵抗の影響を受けない化学反応律速で反応が進行 する場合, 積分反応速度式は次式で表わされる.

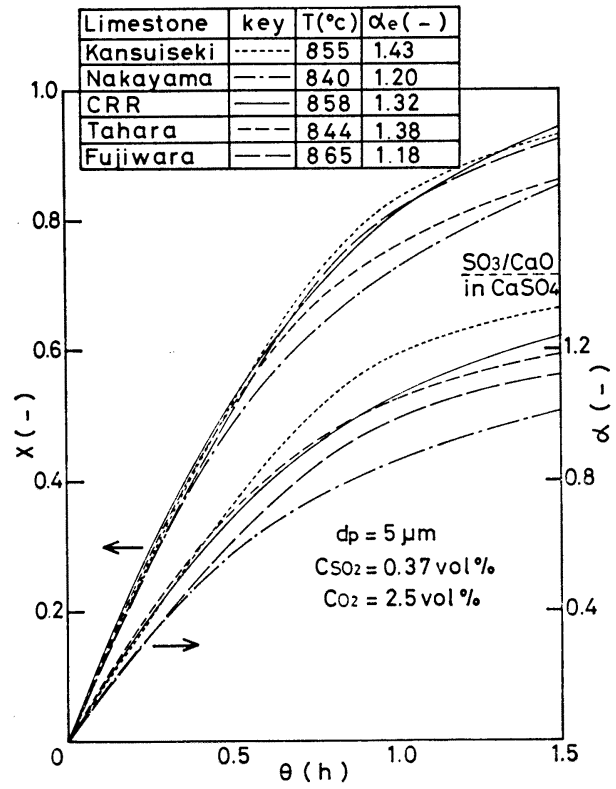

Fig. 1 Comparison of reactivities of ultra-fine CaOpellets (Time-change of $X$ and $\alpha$ )

化学反応津速の場合;

$$
\theta=\frac{r_{g}}{k C_{\mathrm{SO}_{2}}} F_{1}, \quad F_{1}=1-(1-X)^{1 / 3}
$$

反応がグレイン間の空陌内拡散抵抗の影響を受ける場 合には，等温・擬定常状態の仮定下で次式が成立する.

$$
\begin{gathered}
\frac{1}{r^{2}} \frac{\partial}{\partial r}\left(D_{e} r^{2} \frac{\partial C_{\mathrm{SO}_{2}}}{\partial r}\right)-r_{\mathrm{SO}_{2}}=0 \\
r_{\mathrm{SO}_{2}}=f\left(C_{\mathrm{SO}_{2}}, C_{\mathrm{CaO}_{0}}, T, \text { etc }\right)
\end{gathered}
$$

$r_{\mathrm{SO}_{2}}$ は, グレイン基準の反応速度であり，できる限り空 隌払散抵抗の影響を受けない実験条件下 (前報 ${ }^{4}$ ) 同様, $d_{p}=5 \mu \mathrm{m}$ の極微石灰石を用いた実験) で得られた結果 に基づき, Eq. (1) の成立を確認したらえで決定される.

Eq. (2) の初期および境界条件は,

$$
\left.\begin{array}{rl}
\theta=0: & C_{\mathrm{SO}_{2}}=0, r_{\mathrm{SO}_{2}}=0 \\
\theta \geq 0: & r=0 ;\left(\partial C_{\mathrm{SO}_{2}} / \partial r\right)=0 \\
& r=R_{0} ; D_{e}\left(\partial C_{\mathrm{SO}_{2}} / \partial r\right)=k_{f}\left(C_{\mathrm{SO}_{2}, \infty}-C_{\mathrm{SO}_{2}}\right)
\end{array}\right\}
$$

上式中の有効拡散係数 $D_{e}$, 境膜物質移動係数 $k_{f}$ の算 定，理論計算の詳細などは前報 ${ }^{4)}$ と同様である.

\section{3. 結果および考察}

\section{$3 \cdot 1$ 極微粒子 $\left(d_{p}=5 \mu \mathrm{m}\right)$ の反応性}

著者らはさきに， $d_{p}=5 \mu \mathrm{m}$ の極微石灰石（主として 岡山産寒水石）を用いた場合，これを熱分解して生成さ れる $\mathrm{CaO}$ と $\mathrm{SO}_{2}$ との反応は, 空陌拡散抵抗および固 相払散抵抗を注ぼ無視し得る化学反応津速下で進行する ことを明らかにしだ). 本実験においても，前記 5 種の 石灰石の極微粒子について, 同様の検討を行い, 石灰石 


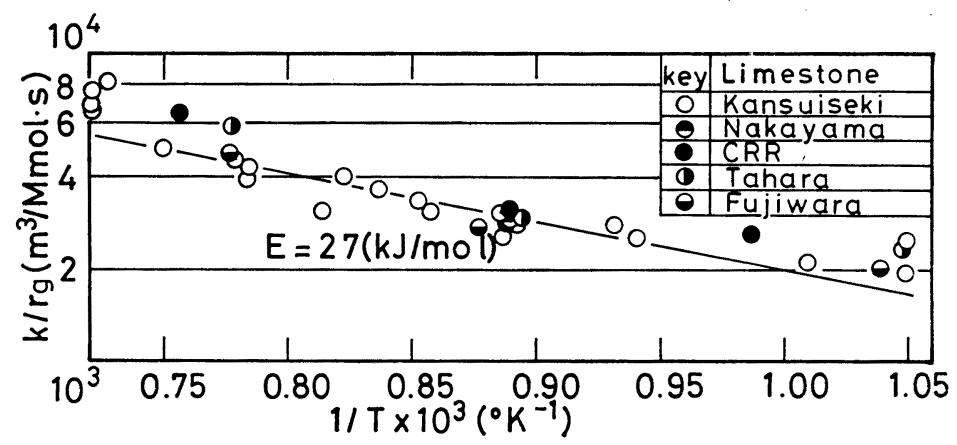

Fig. 2 Comparison of reaction rate constants of five kinds of CaO-pellets employed

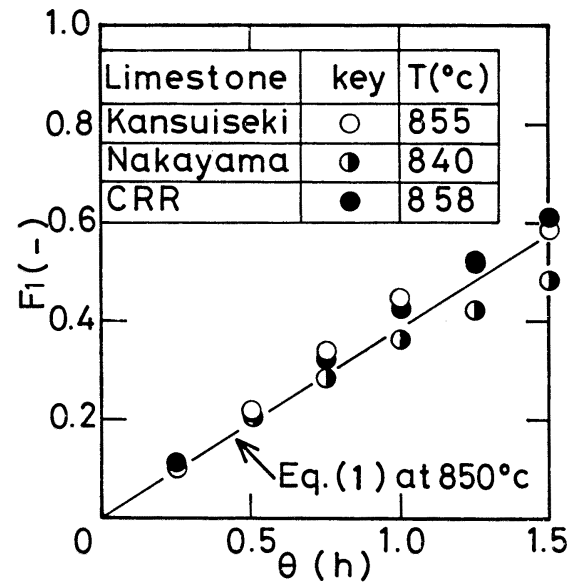

Fig. 3 Result of reproducibility test of experimental data by Eq. (1)

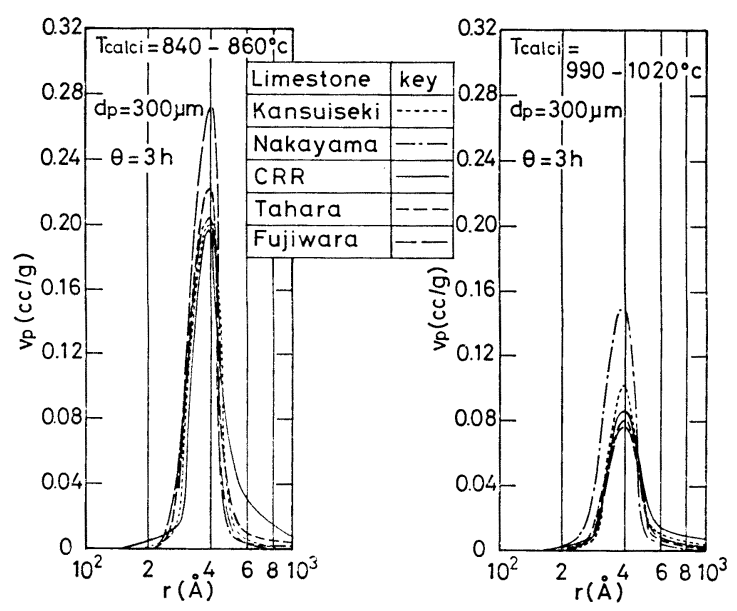

Fig. 4 Pore radius distributions of the $\mathrm{CaO}$-pellets produced by calcination of the limestones employed

種による基礎的反応性の相異を比較した.

いま，反応率 $\left(\mathrm{CaO}\right.$ の $\mathrm{CaSO}_{4}$ への転化率 $) X$ およ

*なお, 湘定にあたり, 熱分解終了後の試料（約 $400 \mathrm{mg}$ ）を $800 \sim$ $850^{\circ} \mathrm{C}$ の高温状態のまま水銀ボロシ用試料ビンに入れ，ただちに吸 引を開始し $\mathrm{CO}_{2}, \mathrm{HO}_{2}$ との反応を極力回避するょう留意した。
び試料単位質量当りの $\mathrm{SO}_{2}$ 吸収率 $\alpha$ をそれぞれ，

$$
\begin{gathered}
X=\frac{1-\left(W / W_{0}\right)}{Y_{0}\left(1-M_{\mathrm{CaSO}_{4}} / M_{\mathrm{CaO}}\right)} \\
\alpha=\left(\frac{W}{W_{0}}\right)-1=\frac{W_{\mathrm{so}_{3}}}{W_{0}}
\end{gathered}
$$

のごとくおき, 前記 5 種の石灰石について, 実験結果を $X$ および $\alpha$ の経時変化として整理したものの 1 例を Fig. 1 に示す. 図から, 反応率の経時変化が, 中山およ び田原産石灰石の場合に反応後期でいくぶん低下してい るものの，いずれも相互に極めて近接した值を示してい ることが認められる. $\alpha$ 值についても, 傾向は同様であ るが，石灰石種間に $\mathrm{CaO}$ 純度に大略対応した相異のあ ることが示されている.なお，図中に $\alpha$ 值の見かけ平衡 值を $\alpha_{e}$ として示したが, その值もほぼ $\mathrm{CaO}$ 純度に比 例した值を示す.

つぎに, Fig. 1 を $F_{1}$ と $\theta$ の関係に整理し, プロッ トした結果, いずれの石灰石に対しても反応率 0.9 程度 まで直線関係が得られた。直線の勾配より, 見かけの反 応速度定数 $\left(k / r_{g}\right)$ を算出し, アレニウス形にプロットし た結果を Fig. 2 に示す. Fig. 1 からも予想されたよう に, 各石灰石の見かけの反応速度定数および活性化エネ ルギーは大略同一值をとることがわかる. Fig. 3 には, Eq. (1)による実験結果の再現性をまとめたものの 1 例 を示す。

以上の実験結果から, 本実験に用いた 5 種の石灰石に ついては, 熱分解生成物中の $\mathrm{CaO}$ 含有率に対応して, $\mathrm{SO}_{2}$ 吸収量に差異があるものの, $\mathrm{SO}_{2}$ に対する基礎的反 応性（見かけの反応速度定数および活性化エネルギー） は石灰石種によらず．ほぼ同一値をとるものと結論され る.

\section{$3 \cdot 2$ 大粒径粒子 $\left(\boldsymbol{d}_{p} \geq \mathbf{3 0 0} \mu \mathrm{m}\right)$ 内の空隙性状}

Figs. 4 (a) および (b) に, $d_{p}=300 \mu \mathrm{m}$ の石灰石を $850^{\circ} \mathrm{C}$ および $1000^{\circ} \mathrm{C}$ にて 3 時間熱分解して得られた $\mathrm{CaO}$ 試料内空淂径分布をそれぞれ示す*. 四から, 空吵 径のピークは, 反応温度および石灰石種によらず, いず れも $400 \AA$ 近辺に存在するが, ピーク高さ (空隚容積) 
Table 2 Pore structure characteristics of calcines

\begin{tabular}{|c|c|c|c|c|c|c|c|c|c|}
\hline \multirow{3}{*}{ Limestone } & \multicolumn{6}{|c|}{$T_{\text {calci }}=850^{\circ} \mathrm{C}$} & \multicolumn{3}{|c|}{$T_{\text {calci }}=1000^{\circ} \mathrm{C}$} \\
\hline & \multicolumn{3}{|c|}{$d_{p}=300 \mu \mathrm{m}$} & \multicolumn{3}{|c|}{$d_{p}=1000 \mu \mathrm{m}$} & \multicolumn{3}{|c|}{$d_{p}=300 \mu \mathrm{m}$} \\
\hline & $v_{p}(\mathrm{cc} / \mathrm{g})$ & $S_{g}\left(\mathrm{~m}^{2} / \mathrm{g}\right)$ & $\varepsilon_{0}(-)$ & $v_{p}(\mathrm{cc} / \mathrm{g})$ & $S_{g}\left(\mathrm{~m}^{2} / \mathrm{g}\right)$ & $\varepsilon_{0}(-)$ & $v_{p}(\mathrm{cc} / \mathrm{g})$ & $S_{g}\left(\mathrm{~m}^{2} / \mathrm{g}\right)$ & $\varepsilon_{0}(-)$ \\
\hline Kansuiseki & 0.37 & 18.5 & 0.57 & 0.47 & 23.5 & 0.63 & 0.26 & 13.0 & 0.48 \\
\hline Nakayama & 0.34 & 17.0 & 0.51 & 0.44 & 22.0 & 0.57 & 0.24 & 12.0 & 0.42 \\
\hline CRR & 0.58 & 29.0 & 0.65 & 0.66 & 33.0 & 0.68 & 0.32 & 16.0 & 0.51 \\
\hline Tahara & 0.40 & 20.0 & 0.57 & 0.46 & 23.0 & 0.61 & 0.20 & 10.0 & 0.40 \\
\hline Fujiwara & 0.39 & 19.5 & 0.56 & 0.43 & 21.5 & 0.59 & 0.22 & 11.0 & 0.42 \\
\hline
\end{tabular}

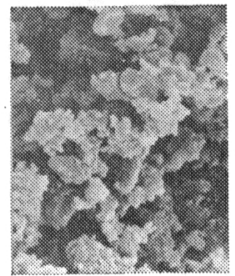

$10 \mu \mathrm{m}$

Raw Limestone

(a) CRR

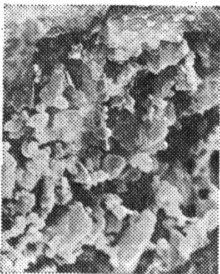

Calcines Tcalci $=850^{\circ} \mathrm{C}, \theta=3 \mathrm{~h}$

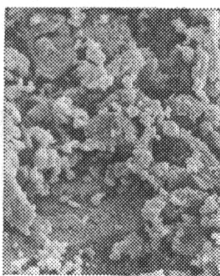

Calcines

Tcalci $=1000^{\circ} \mathrm{C}, \theta=3 \mathrm{~h}$

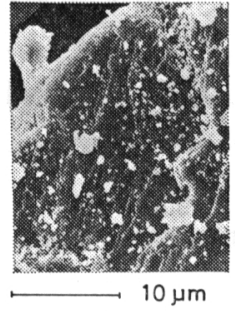

Raw Limestone

(b) Kansuiseki

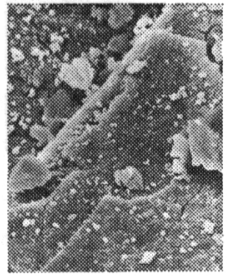

Calcines Tcalci $=850^{\circ} \mathrm{C}, \theta=3 \mathrm{~h}$

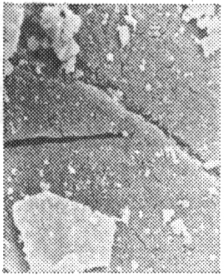

Calcines

Tcalci $=1000^{\circ} \mathrm{C}, \theta=3 \mathrm{~h}$

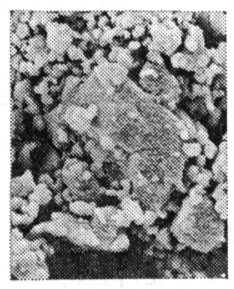

$\theta=0.25 \mathrm{~h}$

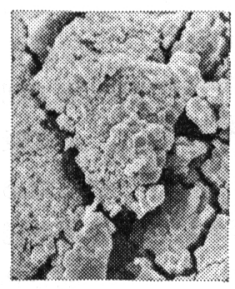

$\theta=1.0 \mathrm{~h}$

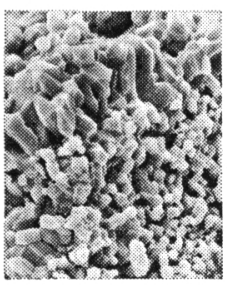

$\theta=3.0 \mathrm{~h}$

(c) CRR - Sulfate (Tcalci $\left.=\mathrm{Tsul}=850^{\circ} \mathrm{C}\right)$ 


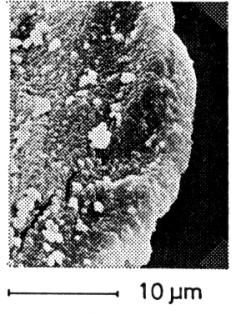

$\theta=0.25 \mathrm{~h}$

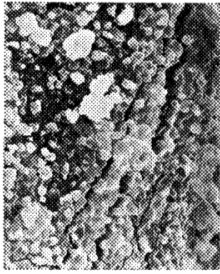

$\theta=1.0 h$

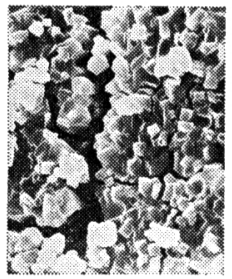

$\theta=3.0 \mathrm{~h}$

(d) Kansuiseki - Sulfate $\left(T_{\text {calci }}=T_{\text {sul }}=850^{\circ} \mathrm{C}\right)$

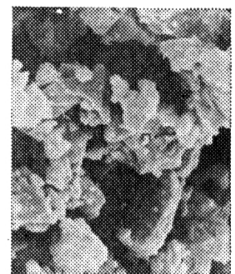

$\longmapsto \quad 1 \mu \mathrm{m}$

Raw Limestone

(e) CRR

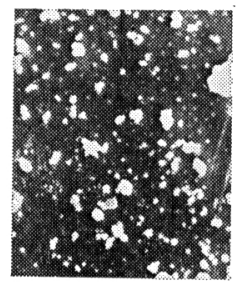

$\longmapsto \quad 1 \mu m$

Raw Limestone

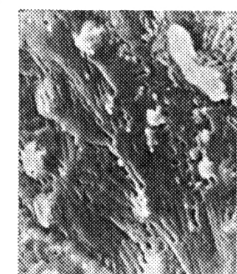

1

Calcines Tealci $=850^{\circ} \mathrm{C}, \theta=3 \mathrm{~h}$
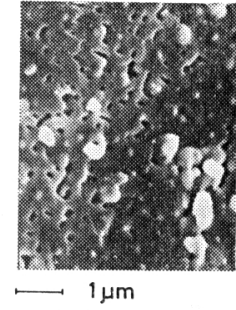

Calcines

Tcalci $=1000^{\circ} \mathrm{C}, \theta=3 \mathrm{~h}$

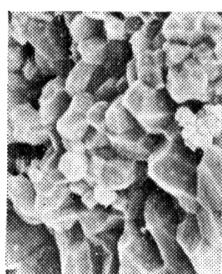

$\longmapsto 1 \mu \mathrm{m}$

Sulfate

Tsul $=850^{\circ} \mathrm{C}, \theta=3 \mathrm{~h}$

(f) Kansuiseki

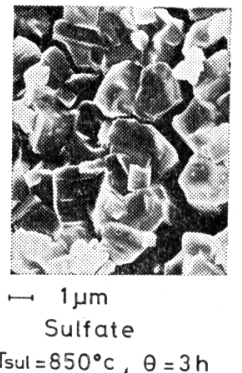

Fig. 5 Scanning electron micrographs of the limestone, calcined and partially sulfated sample pellets

は, $1000^{\circ} \mathrm{C}$ の場合, $850^{\circ} \mathrm{C}$ の場合に比べ著しい低下の あることが認められる。

Table 2 に, $d_{p}=300 \mu \mathrm{m}$ および $1000 \mu \mathrm{m}$ の前記石 灰石を $850^{\circ} \mathrm{C}$ あるいは $1000^{\circ} \mathrm{C}$ にて 3 時間熱分解して 得られた $\mathrm{CaO}$ 粒子の空隌性状について，いくつかの特 性値を計算した結果（空隙径 $15 \mu \mathrm{m}$ 以下の空隙を対象 とした）の 1 例を示す.なお, 比表面積 $S_{g}$, 空隌率 $\varepsilon_{0}$ は，それぞれ次式により求め，代表半径 $r^{*}$ 汇は Fig. 4 に括游るピーク空隙半径をあてた。

$$
\begin{gathered}
S_{g}=\frac{2 U_{p}}{r^{*}} \\
\varepsilon_{0}=\frac{v_{p}}{\left(1 / \rho_{s}+v_{p}\right)}
\end{gathered}
$$

表から，各值は，熱分解温度および粒径により異なっ ているが，試料間の相異についてはいずれの特性值も，
CRR の值が他に比し高いことが認められる。

Fig. 5 (a)-(f) に, 原石灰石, 熱分解生成物, 硫酸化 反応生成物打の括のの SEM とよる表面写真の 1 例を示 す.まず，Fig. 5 (a) により CRR 原石と熱分解生成物 とを比較すると, 原石には認められない微細な空吵が熱 分解後泩成していること, また CRR 原石の表面は極 めて凹凸がはげしく，比較的大きな空隙の存在すること が示唆される.一方，(b) の寒水石は極めて繳密な結晶 体であり, 熱分解後汇多少の亀裂は生ずるものの, 大空 㭞の発達は見られず，CRR と同様の微細空淂のみが生 成されている. (c) には，CRR についての硫酸化反応過 程が示されているが，反応進行化い，極めて滑らかな 表面を持つ緻密な結晶グレインの再生成されていく様子 が認められる。（d）は寒水石の場合であり，反応生成物 


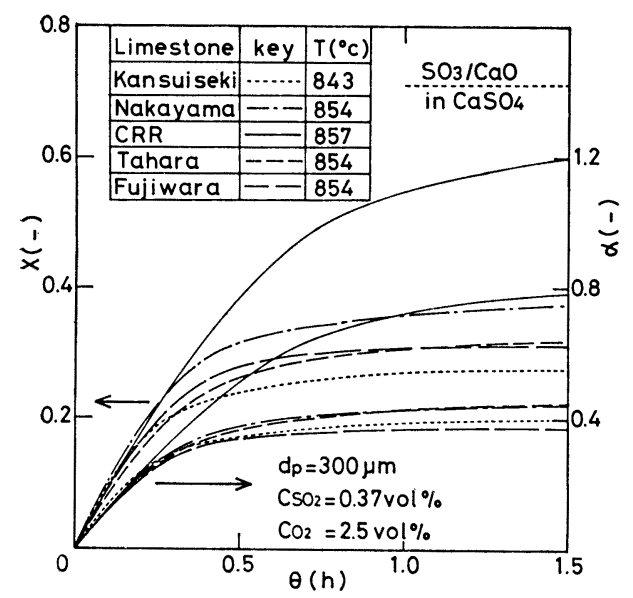

Fig. 6 Comparisons of time-change of $X$ and $\alpha$ between the five kinds of limestone pellets with diameter of $300 \mu \mathrm{m}$

の形態は (c) と同様であるが，反応に伴い粒子が多少膨 張する傾向があるようである. (e) および (f) は, (a)-(d) の局所払大図の 1 例である.

\section{$3 \cdot 3$ 粒径增大に伴う空隙拡散抵抗の影響}

Fig. 6 に, $d_{p}=300 \mu \mathrm{m}$ の各種石灰石を用いた場合に ついて, Fig. 1 と同様に反応率 $X$ および $\mathrm{SO}_{2}$ 吸収率 $\alpha$ の経時変化の形で実験結果を整理したものの 1 例を示 す. Fig. 1 と比較してわかるよらに，いずれの石灰石 においてもこの粒径で空隌拡散抵抗の影響を明確に受け ているが, CRR の $X$ および $\alpha$ 值がともに, 他の石灰 石の值に比し, 反応初期（反応時間 30 分以内）を除 き，極めて高い值を示すことが認められる．CRRを 除 く他の石灰石に関しては， $X$ 値に多少の差違があるもの の, $\alpha$ 值は相互に極めて近接した值を示し, Fig. 1 の $\mathrm{CaO}$ 含有率に対応した有意差はこの場合消隇している. 以上の結果から, 粒径増大に伴って原石中の初期空隙率 の影響が現れ，硫黄吸収容量を基準として脱硫剤の優 劣を比較するかぎり多孔性でかつ比較的 $\mathrm{CaO}$ の純度も 高いCRR が他の石灰石に比し優れた脱硫剤となり，高 純度, 高結晶性であっても, 初期空隙率の未発達なもの は FBC 脱硫剤として, 問題があることなどが推論し得 る.

Fig. 7 には，3 種の石灰石を例にとり，熱分解温度の 影響について, 理論解析結果とも対比して示してある. なお, 理論解析結果は, Eqs. (2)-(5) を差分化し数值積 分することにより求めたが，実計算にあたり，固体粒子 の分割および迷宮率 $て$ の見積りを, 前報 ${ }^{4)}$ と同様, 以下 の通りとした。

i）粒子表面部分を $4 \mu \mathrm{m}$ 厚さの球殼に分割し，この 部分は反応津速, これ以外の部分は空隙払散の影響を受

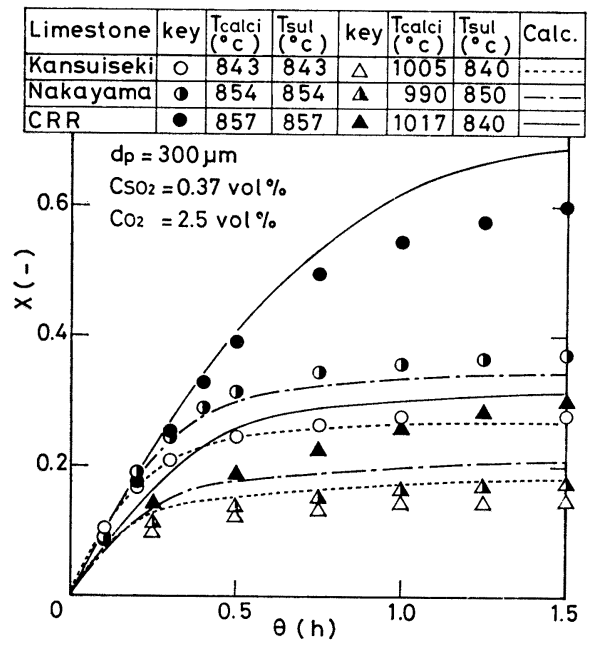

Fig. 7 Comparisons of experimental results with theoretical results (Effect of intrapellet diffusion on overall rate)

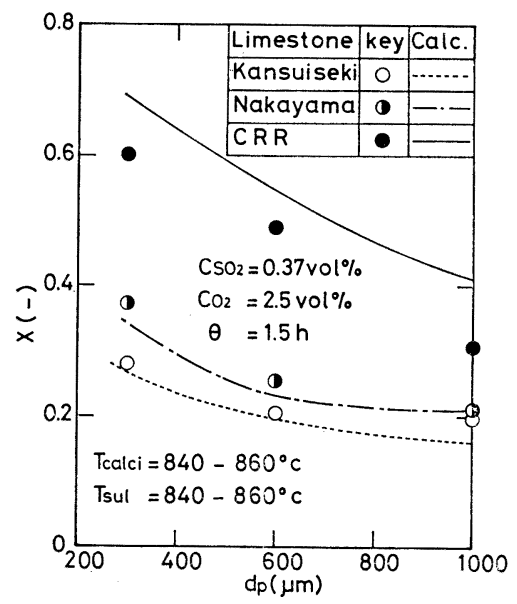

Fig. 8 Effect of the pellet diameter on the conversion

ける・

ii) $\tau=(1 / \varepsilon)^{p}, p=\left(\varepsilon_{0} / \varepsilon\right)$

また, $\mathrm{CaO}$ 粒子の各物性值は Tables 1 および 2 の各 值を用いた。

図から，熱分解温度の上昇に伴い，粒子内空隙容積の 低下のため，総括反応速度が著しく低下する傾向が，い ずれの石灰石に対しても認められ，たとえ CRRのよう な初期空隌の多い試料であっても，熱分解温度の選定い かんで著しい反応性低下を受けることがわかる．これら の傾向を理論解析結果は比較的良好に再現しており，反 応進行に伴う空隙閉塞とそれへの有効な対応が試料選定 の重要な基準であると考える本報の論点が，妥当なもの であることを示しているものと思われる.

Fig. 8 には, Fig. 7 の結果を整理し， 3 種の石灰石 
について, 反応時間 $1.5 \mathrm{~h}$ に打ける反応率を粒径に対し プロットしなおした結果が示されている.

\section{結言}

$d_{p}=5 \mu \mathrm{m}$ の 5 種の極微石灰石を熱分解して生成され る $\mathrm{CaO}$ と $\mathrm{SO}_{2}$ との反応事験を, 熱天科を用い, 反応 温度 $700-1100^{\circ} \mathrm{C}$ にて行い，その基礎的反応性を石灰 石種について比較検討した. ついで, $d_{p}=300-1000 \mu \mathrm{m}$ の比較的大粒径粒子を用い，これらからの熱分解生成粒 子内空陌性状, 硫酸化反応に伴ら空隙および粒子形態変 化, 総括反応速度に与える空隍拡散抵抗の影響などにつ いて，検討を行った。

その結果, $d_{p}=5 \mu \mathrm{m}$ の極微粒子を用いた場合, 空隌 拡散抵抗の影響をほぼ無視でき，同時に上記各石灰石の $\mathrm{SO}_{2}$ に対する基礎的反応性は大略同一であることがわか った. $d_{p}=300-1000 \mu \mathrm{m}$ の熱分解生成粒子内空陌容積 は, 石灰石種, 熱分解温度などにより影響を受け，とく にCRR のその值は他に比し著しく高いこと, 熱分解温 度により最大容積を持つ空隙径 (ピーク空隙径) は変化 しないが，空隙容積は，本実験条件下では，その上昇と ともに減少することなどを認め, またこれら空隙が硫酸 化反応進行に伴い減少, 閉塞する様子を SEM 観察によ り示した.これらの特性をもとに，総括反応速度と粒径 の関係を検討した結果, 総括反応速度に与える空隙払散 抵抗の影響は，粒径増大に伴い顕著となるが，初期空 隙率, 熱分解温度によってその影響が異なり, 熱分解後 の $\mathrm{CaO}$ 粒子の空隙率が重要であることを, あらためて 明らかにした。

[謝辞]本実験を行らにあたり，秩父セメント (株) より試料の提供および SEM 観察に対する御助力 を受けたここに謝意を表する。

\section{Nomenclature}

\begin{tabular}{|c|c|c|c|}
\hline$C$ & $=$ & concentration of reactant & {$\left[\mathrm{mol} / \mathrm{m}^{3}\right]$} \\
\hline$D_{e}$ & $=$ & effective diffusivity & {$\left[\mathrm{m}^{2} / \mathrm{s}\right]$} \\
\hline$D_{s}$ & $=$ & solid diffusivity & {$\left[\mathrm{m}^{2} / \mathrm{s}\right]$} \\
\hline & $=$ & reaction rate constant & $\left.\mathrm{n}^{4} / \mathrm{mol} \cdot \mathrm{s}\right]$ \\
\hline$k_{f}$ & $=$ & $\begin{array}{l}\text { mass transfer coefficient on the exte } \\
\text { surface of sample pellet }\end{array}$ & {$[\mathrm{m} / \mathrm{s}]$} \\
\hline$M$ & $=$ & molecular weight & {$[\mathrm{kg} / \mathrm{mol}]$} \\
\hline & $=$ & $\begin{array}{l}\text { radial distance from the center of } \\
\text { sample pellet }\end{array}$ & {$[\mathrm{m}]$} \\
\hline$r_{g}$ & $=$ & stal grain & [m] \\
\hline$S_{g}$ & $=$ & specific surface of sample pellet & {$\left[\mathrm{m}^{2} / \mathrm{kg}\right]$} \\
\hline$T$ & $=$ & rature & {$\left[{ }^{\circ} \mathrm{C}\right]$} \\
\hline$v_{p}$ & $=$ & e pellet & {$[-]$} \\
\hline$W$ & $=$ & weig & {$[\mathrm{kg}$} \\
\hline$W_{0}$ & $=$ & initi & {$[\mathrm{kg}]$} \\
\hline$W_{\mathrm{SO}_{3}}$ & & weight of $\mathrm{SO}_{3}$ within sample pellet & {$[\mathrm{kg}]$} \\
\hline$X$ & $=$ & conversion of sulfation & {$[-]$} \\
\hline$Y_{0}$ & $=$ & $\begin{array}{l}\text { weight fraction of solid reactant in } \\
\text { sample pellet }\end{array}$ & $\mathrm{n}$ \\
\hline$\varepsilon$ & & $\begin{array}{l}\text { porosity within sample pellet at } \\
X=X\end{array}$ & {[} \\
\hline$\varepsilon_{0}$ & & $\begin{array}{l}\text { initial porosity within sample } \\
\text { pellet }\end{array}$ & {$[-$} \\
\hline$\rho_{s}$ & $=$ & true density of sample pellet & \\
\hline & $=$ & tortuosity factor & $\Gamma$ \\
\hline
\end{tabular}

\section{Literature cited}

1) Borgwardt, R. H. and R. H. Harvey: Envi. Sci. \& Tech., 6, 350 (1972)

2) Dogu, T.: Chem. Eng. Journal, 21, 213 (1981)

3) Hartman, M., J. Pata and R. W. Coughlin: Ind. Eng. Chem. Proc. Des. Dev., 17, 411 (1978)

4) Hasatani, M., M. Yusawa and N. Arai: Kagaku Kogaku Ronbunshu, 8, 45 (1982)

5) Pigford, R. L. and G. Sliger: Ind. Eng. Chem. Proc. Des. Dev., 12, 85 (1973)

6) Szekely, J., J. W. Evans and H. Y. Sohn: “Gas-Solid Reaction", Academic Press, New York (1976)

(1983 年 2 月 28 日受理; 化学工学協会姫路大会 (姫路, 1982 年 7 月) にて一部発表)

\title{
Comparison of Reactivity of $\mathrm{CaO}$ Pellets Produced by Calcination of Various Kinds of Limestone in the Reaction with $\mathrm{SO}_{2}$
}

\author{
Megumu Yusawa* and Masanobu Hasatani
}

Dept. of Chem. Eng., Nagoya Univ., Nagoya 464

Key Words: Environment, Fluidized Bed Combustion, Calcium Oxide Pellet, Reactivity, Sulphite Oxide Saturation Capacity

For the suitable selection of calcium-based sorbents of $\mathrm{SO}_{2}$ in $\mathrm{FBC}$ of coal, reactivities of $\mathrm{CaO}$ pellets prepared by calcination of various kinds of limestones were compared on the basis of the results from a TGA study within the range of reaction conditions: temperature, 
$700-1100^{\circ} \mathrm{C}$ and pellet diameter, $5-1000 \mu \mathrm{m}$.

For ultra-fine pellets $(5 \mu \mathrm{m})$, the chemical reaction rate controls the overall rate and there is hardly any variation in $\mathrm{SO}_{2}$ reactivity among the $\mathrm{CaO}$ pellets employed.

For $\mathrm{CaO}$ pellets larger than $300 \mu \mathrm{m}$, the intrapellet pore volume decreases as the calcination temperature rises. Pellets prepared from Coral Reef Rock (CRR) have the largest value of pore volume among the $\mathrm{CaO}$ pellets employed.

With increase in pellet diameter, the effect of intrapellet diffusion rate of $\mathrm{SO}_{2}$ on the overall rate becomes increasingly significant but depends largely upon the initial pore volume of the $\mathrm{CaO}$ pellet, i.e. calcination temperature and original limestone. As a result, the $\mathrm{CaO}$ pellets prepared from CRR have the largest value of $\mathrm{SO}_{2}$-saturation capacity.

* Dept. of Civil Eng., Gunma Univ. 